\title{
Methods for the Evaluation of Waste Treatment Processes
}

\author{
Hans-Joachim Gehrmann, ${ }^{1}$ Markus Hiebel, ${ }^{2}$ and Franz-Georg Simon ${ }^{3}$ \\ ${ }^{1}$ KIT Karlsruher Institut für Technologie, Institut für Technische Chemie (ITC), 76344 Eggenstein-Leopoldshafen, Germany \\ ${ }^{2}$ Fraunhofer-Institut für Umwelt-, Sicherheits- und Energietechnik UMSICHT, Osterfelder Str. 3, 46047 Oberhausen, Germany \\ ${ }^{3}$ BAM Bundesanstalt für Materialforschung, Unter den Eichen 87, 12205 Berlin, Germany \\ Correspondence should be addressed to Franz-Georg Simon; franz-georg.simon@bam.de
}

Received 23 May 2017; Revised 18 August 2017; Accepted 10 September 2017; Published 25 October 2017

Academic Editor: Shanmugam Kumaran

Copyright (C) 2017 Hans-Joachim Gehrmann et al. This is an open access article distributed under the Creative Commons Attribution License, which permits unrestricted use, distribution, and reproduction in any medium, provided the original work is properly cited.

\begin{abstract}
Decision makers for waste management are confronted with the problem of selecting the most economic, environmental, and socially acceptable waste treatment process. This paper elucidates evaluation methods for waste treatment processes for the comparison of ecological and economic aspects such as material flow analysis, statistical entropy analysis, energetic and exergetic assessment, cumulative energy demand, and life cycle assessment. The work is based on the VDI guideline 3925. A comparison of two thermal waste treatment plants with different process designs and energy recovery systems was performed with the described evaluation methods. The results are mainly influenced by the type of energy recovery, where the waste-to-energy plant providing district heat and process steam emerged to be beneficial in most aspects. Material recovery options from waste incineration were evaluated according to sustainability targets, such as saving of resources and environmental protection.
\end{abstract}

\section{Introduction}

In $2014239 \times 10^{6}$ megagrams (Mg) of Municipal Solid Waste (MSW) were generated in the $28 \mathrm{EU}$ countries [1]. This equals $475 \mathrm{~kg}$ MSW per capita, $23 \mathrm{~kg}$ MSW per 1000 Euros of Gross Domestic Product (GDP), and $36 \mathrm{~kg}$ MSW per Mg of Domestic Material Consumption (DMC, the total amount of material directly used in an economy). The amount of MSW rose from $227 \times 10^{6} \mathrm{Mg}$ in the year 1995 to $259 \times 10^{6} \mathrm{Mg}$ in 2008. Since then falling numbers are observed in Europe. The applied treatment options differ substantially between the EU countries as can be seen from Figure 1 [1].

On EU average $28 \%$ of MSW are recycled, $16 \%$ composted, and $27 \%$ incinerated. Nevertheless $28 \%$ are still landfilled, mostly without any pretreatment. Landfilling falls under the lowest treatment category of the EC waste hierarchy [2]. The lowest share of landfilling is from the following six countries: Austria, Belgium, Denmark, Germany, The Netherlands, and Sweden, each tallying below 5\%. The waste treatment processes for recycling, composting, and incineration are manifold. Figure 2 displays flows of MSW in Germany (data from [3]). Here the waste management consists of composting for garden waste and biowaste, mechanicalbiological treatment (MBT) of mixed waste, combustion of waste wood and Refuse-Derived Fuels (RDF) in cogeneration plants (Combined Heat and Power, CHP), incineration of mixed waste in waste-to-energy (WtE) plants, and recycling of waste materials from separate collection organized by curbside pickup or bring-systems [4]. Recycling includes treatment resulting in materials and energy recovery as well as in thermal treatment in WtE plants (e.g., sorting residues) [5].

A sustainable waste management system aims at maximizing materials and energy recovery while minimizing environmental impacts and societal cost associated with all treatment and collection steps [6]. The decision regarding which treatment process is used for what kind of waste fulfilling certain sustainability objectives is often difficult and depends on various boundary conditions. Sustainability objectives could be maximum materials recovery to save natural resources, minimum emissions to the environment, lowest treatment cost, highest concentrating efficiency for pollutants, and so on. Evaluation methods are therefore required to assess various waste management strategies. 


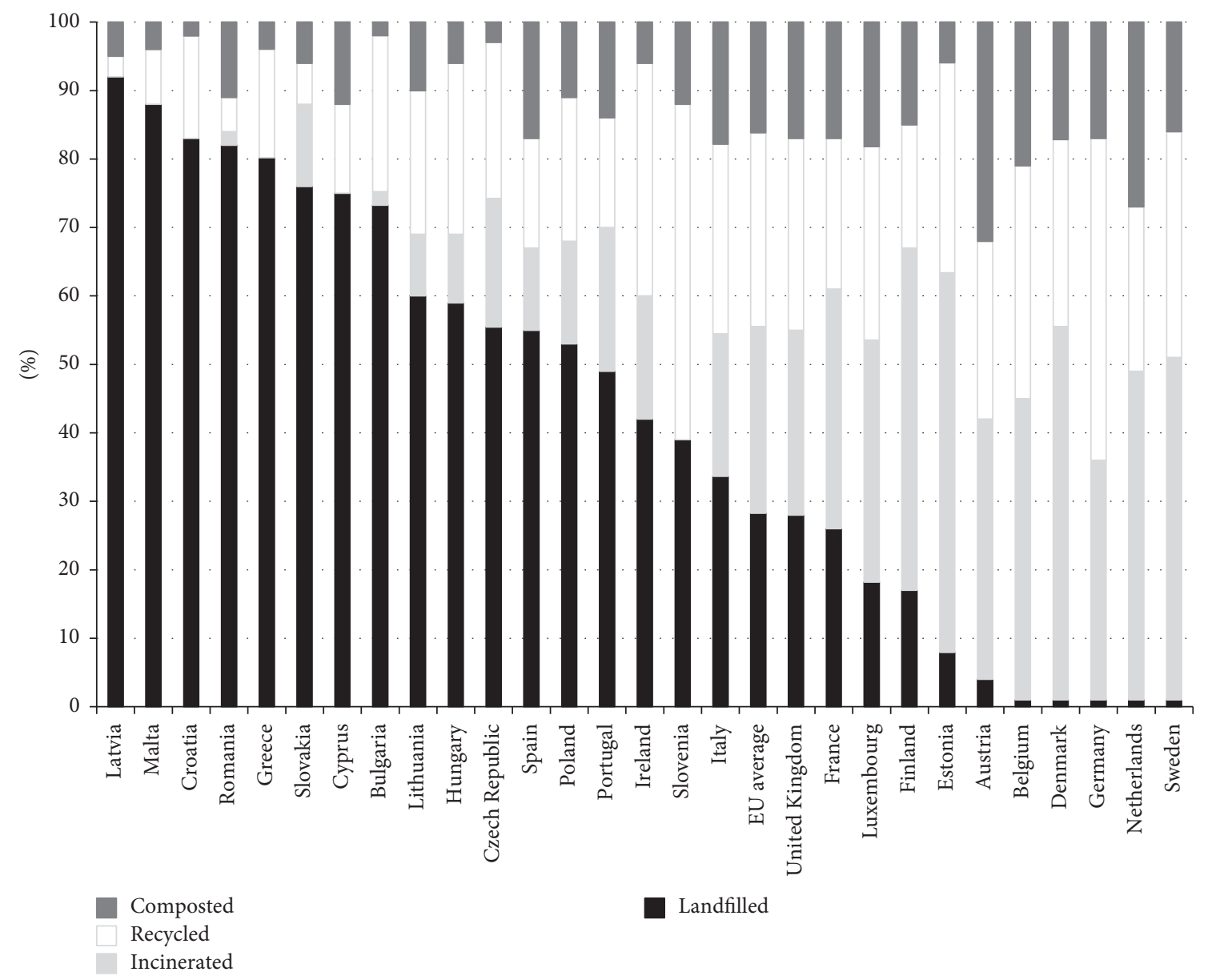

FIGURE 1: Share of the different treatment options in the 28 EU countries in the year 2014 [1].

With more than 152,000 members, VDI (Verein Deutscher Ingenieure, German Association of Engineers) is one of Western Europe's biggest science and technology associations and, next to the German Institute for Standardization (DIN), the most important source of technical guidelines and standards in Germany. Given its wide-ranging base of technical expertise, VDI decided in 2008 to adopt the evaluation of waste treatment processes as an interdisciplinary topic. The objective was to describe available evaluation methods in waste management together with their opportunities and limits [7]. The outcome of this work was VDI guideline 3925. The final version of descriptive part 1 of this standard was released in September 2016 [4]. In part 2 the methods were applied to a practical example, the process comparison of two alternative waste-to-energy plants. The draft version of VDI 3925, part 2, appeared in July 2016 [8]. The results of the comparison and the interlinkage to sustainability assessment will be discussed in the present work.

\section{System Boundaries and Input Data}

An adequate methodology has to be selected to respond to the questions of which waste treatment option is the best with respect to sustainability, which is the most profitable investment, and so on. The accuracy of the results however depends strongly on the input parameters and the boundary conditions.

To evaluate the various evaluation methods outlined earlier, two WtE plants were chosen, based on real plant data, but with some modifications which will be explained in later sections. In Figure 3, an overview of various evaluation methods is shown; part of them will be explained in this paper to support the understanding of results.

The first main column comprises the mass and material balances for the processes including the climate change relevant $\mathrm{CO}_{2}$ balance. If the mass balance is not equalized the resultant enthalpy flows and all connected aspects like exergy analysis and efficiencies would be erroneous. The waste composition data for this paper is based on the average German waste composition concerning the main elements like carbon, hydrogen, and oxygen. Sulfur, chlorine, and trace elements were set in accordance with VDI 3460 [9]; see Table 1. The net calorific values (NCV) of the waste were proposed to be $9.72 \mathrm{MJ} / \mathrm{kg}$ and adapted by changing the water content of the waste, while the ash content (sum of bottom ash and fly ash) should be constant at $27.5 \mathrm{wt} . \%$.

The second column presents the energy balance. From the energy balance the required amounts of feeding water 


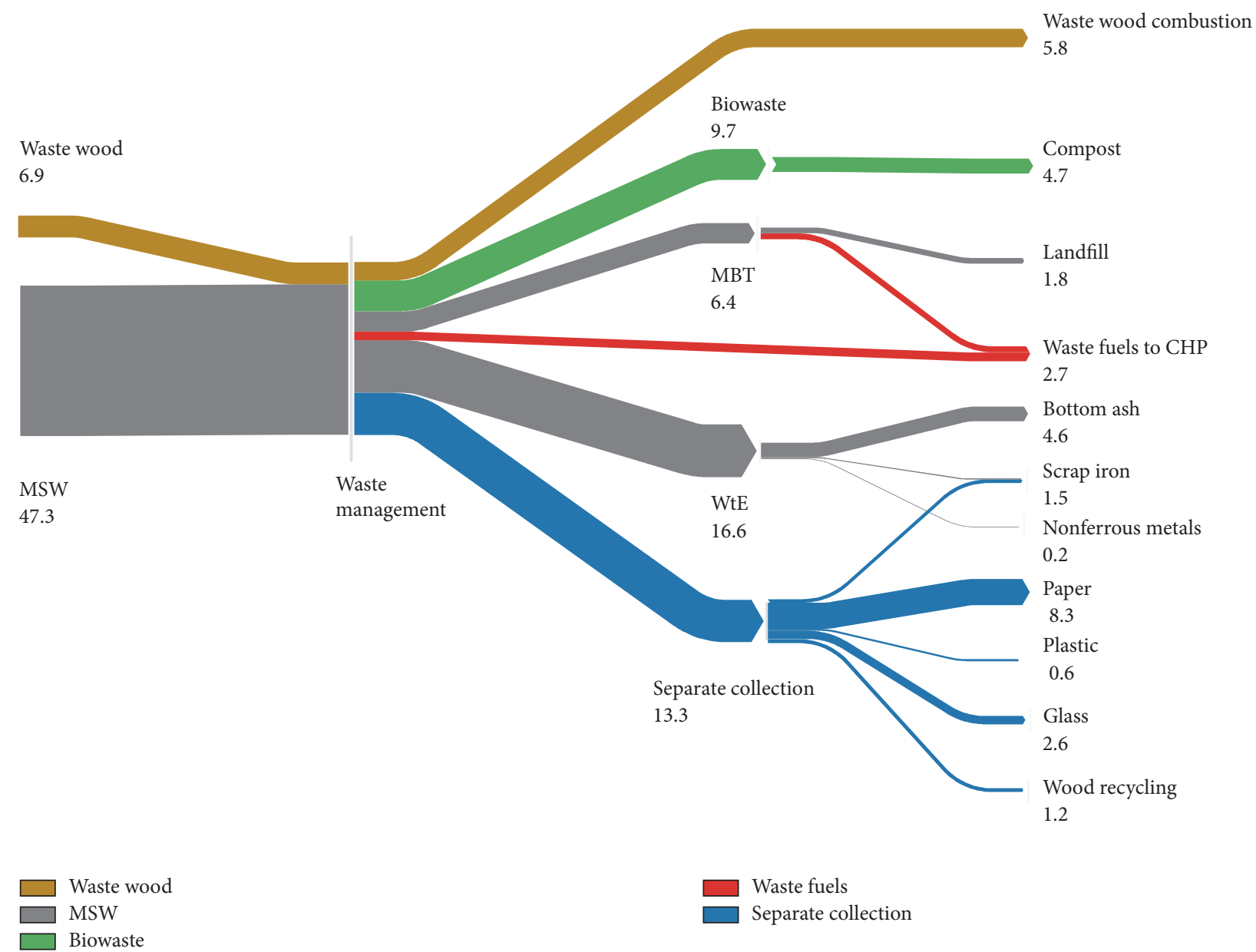

FIgURE 2: Flows of MSW in Germany (numerical data in $10^{6} \mathrm{Mg}$ from [3]).

for the boiler were calculated. Based on mass and energy balance the distribution of materials could be calculated not only by the state-of-the-art balancing scheme for each species but also by entropy analysis which points out sources and sinks of pollutants of each process. The life cycle assessment emphasizes the impacts of certain species on the environment with, for example, the global warming potential (GWP), the acidification potential (AP), or the human toxicity potential (HTP).

The eco-efficiency analysis emphasizes the monetary weighting of the life cycle assessment. The economy of the processes is evaluated by the cost-benefit analysis. Social aspects are included by the social-eco-efficiency analysis.

To balance the single processes local and time-dependent boundary conditions exist: The local system boundary is the delivery of the waste to the WtE plant (including operating consumables) and on the output side the ash discharger for solid residues and the smokestack for the flue gas. Timedependent boundary is the operating life of 20 years.

To wrap up the main differences on the plants, Figure 4 displays the WtE process chains. The heat-conducted WtE plant generates heat and electricity and the power-conducted WtE plant generates electricity only.
The first WtE plant in this comparison is heat conducted with minor production of power and the second WtE plant is power conducted with no heat outcome. The main thermal process and the combustion conditions like air ratio, temperatures, and so on are assumed to be identical. The flue gas treatment however differs: While the heat-conducted process is based on a wet flue gas treatment with two scrubbers with the possibility of discharging the purified waste water into receiving water, the second plant is operated wastewater-free. Both plants are using a SCR technology for $\mathrm{NO}_{x}$ reduction.

To calculate all characteristic parameters for the discussed methods in Figure 3 the necessary input data are summarized in Table 1. The operation time of both the plants is about $7,600 \mathrm{hrs}$ per year for a capacity of $212,800 \mathrm{Mg}$ of waste (corresponding to a waste flow of $28 \mathrm{Mg} / \mathrm{hr}$ ).

\section{Evaluation Methods}

3.1. Material Flow Analysis. The material flow analysis is a methodology to model and evaluate complex systems for the optimization of ecological and economical aspects in private and public sector. The material flow analysis reduces 


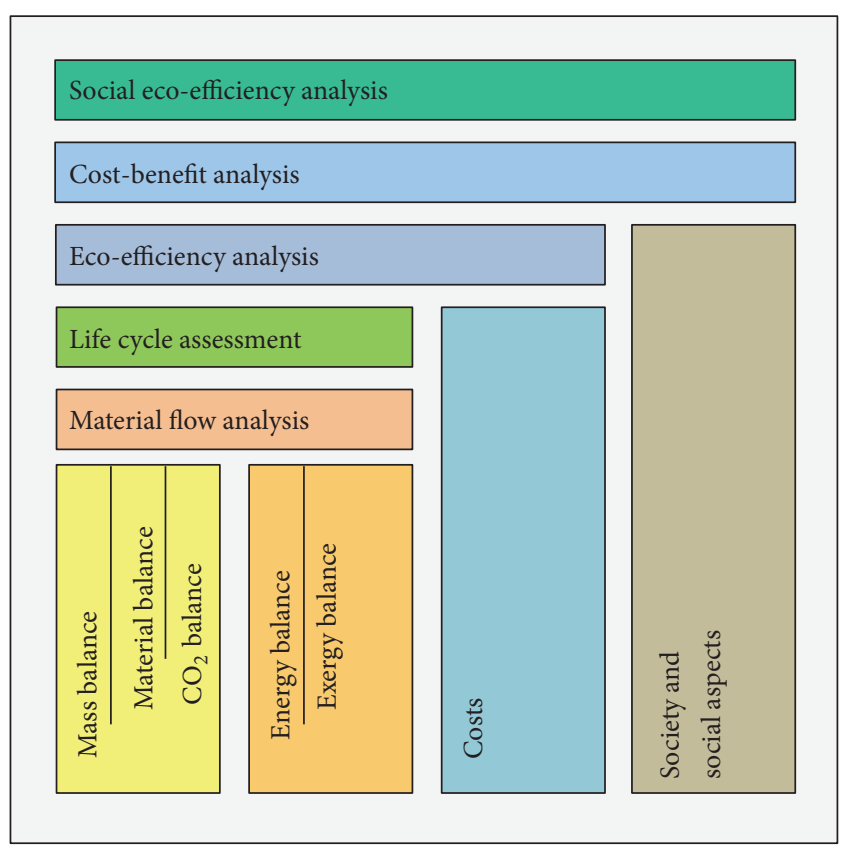

Figure 3: Overview of the methods used for the evaluation of processes.

TABLE 1: Waste composition as input for both WtE plants.

\begin{tabular}{|c|c|}
\hline Waste composition & Value (wt. $\%$ as received) \\
\hline Water & 30.90 \\
\hline Bottom ash & 22.00 \\
\hline Fly and filter ash & 3.00 \\
\hline $\mathrm{C}$ & 22.55 \\
\hline $\mathrm{H}$ & 4.15 \\
\hline $\mathrm{N}$ & 0.91 \\
\hline $\mathrm{O}_{\text {diff }}$ & 14.78 \\
\hline Total S & 0.32 \\
\hline Total Cl & 1.39 \\
\hline Sum & 100.00 \\
\hline $\mathrm{NCV}$ & 9.720 \\
\hline Trace elements (chemically bound) & Value (mg/kg) \\
\hline As & 2.10 \\
\hline $\mathrm{Sb}$ & 48.0 \\
\hline $\mathrm{Cr}_{\text {ges }}$ & 290.0 \\
\hline $\mathrm{Ni}$ & 180.0 \\
\hline $\mathrm{Cd}$ & 15.0 \\
\hline $\mathrm{Cu}$ & 2590.0 \\
\hline $\mathrm{Pb}$ & 560.0 \\
\hline $\mathrm{Zn}$ & 1790.0 \\
\hline $\mathrm{Hg}$ & 0.740 \\
\hline Elemental metals in MSW & Value (wt.\%) \\
\hline $\mathrm{Fe}$ & 15.550 \\
\hline $\mathrm{Al}$ & 1.80 \\
\hline $\mathrm{Cu}$ and brass & 0.250 \\
\hline
\end{tabular}

TABLE 2: Transfer coefficients onto the different output fractions for $\mathrm{Hg}$ in both options.

\begin{tabular}{lcc}
\hline & Heat-conducted & Power-conducted \\
& \multicolumn{2}{c}{$k_{\mathrm{Hg}}[\mathrm{wt} . \%]$} \\
\hline Flue gas & 3.90 & 3.90 \\
Waste water & 0.30 & 0.00 \\
Bottom ash & 4.93 & 4.93 \\
Fly ash and FGT residues & 4.60 & 91.17 \\
Gypsum & 3.27 & 0.00 \\
Sludge & 83.00 & 0.00 \\
Cu scrap & 0.00 & 0.00 \\
Al scrap & 0.00 & 0.00 \\
Fe scrap & 0.00 & 0.00 \\
\hline Sum & 100.00 & 100.00 \\
\hline
\end{tabular}

complex systems to relevant goods and processes for further measurements [10]. Examples are material balances in sorting processes or as described in this paper in different waste treatment processes. The material flow analysis employed in this paper was developed in Switzerland and is described in two regulations in Austria (ÖNORM S 2096-1 and -2). A software tool for modelling was developed at the Vienna University of Technology [10]. In a first step the system boundaries have to be defined as it is already mentioned in the earlier section. In a second step the processes have to be defined, such as the incinerator and flue gas treatment as "black boxes" with input mass flows $\left(F_{\text {input }, i}\right)$ and output mass flows $\left(F_{\text {output }, i}\right)$. The decision on which species the material flow analysis should focus on is given by the research question. In the outlined examples in Section 4, the distribution of $\mathrm{Hg}, \mathrm{Zn}$, and $\mathrm{Cl}$ in input and output flows is presented. The distribution of the elements in the output is based on transfer coefficients $k_{i}$ for each process which are known from literature or have to be experimentally determined. The transfer coefficient $k_{i}$ is defined as

$$
k_{i}=\frac{F_{\text {output }, i}}{\sum_{i=1}^{n} F_{\text {input }, i}} \text { with } \sum_{j=1}^{m} k_{i, j}=1 .
$$

As an example, for $\mathrm{Hg}, k_{\mathrm{Hg}}$ in wt.\% is given in Table 2 for both processes.

3.2. Statistical Entropy Analysis. Based on the material flow analysis in Section 3.1 a statistical entropy analysis can be performed to assess the ability of a system to concentrate or dilute substances [11]. In this case the entropy is a measure for the dispersion of any distribution. Hence it could be applied for the distribution of materials in processes. One of the main questions in waste management processes is how to recycle as many as possible from the wastes with low effort of energy. From the thermodynamic point of view much more effort (e.g., energy) is needed to concentrate or extract a material when it is highly diluted than when it is less diluted in a volume or mass flow. For a dilution of material, the statistical entropy is increasing, while concentrating the statistical entropy is decreasing. For a circular economy, it 


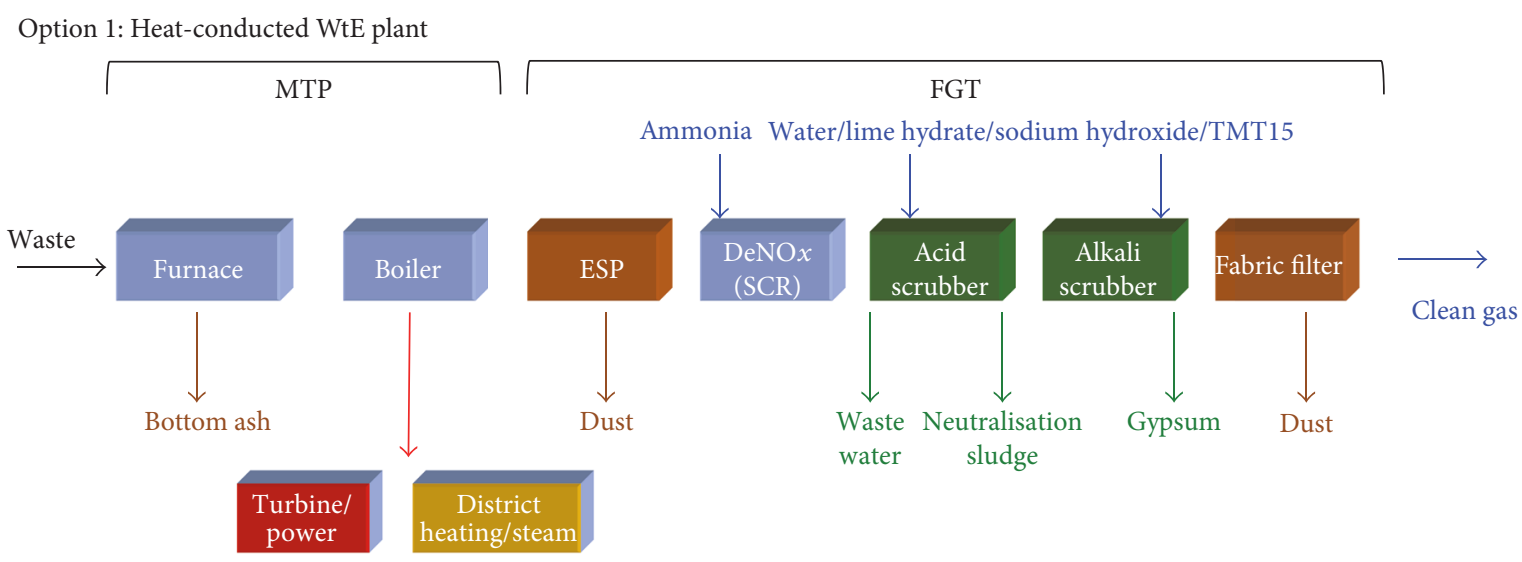

(a)

Option 2: Power-conducted WtE plant

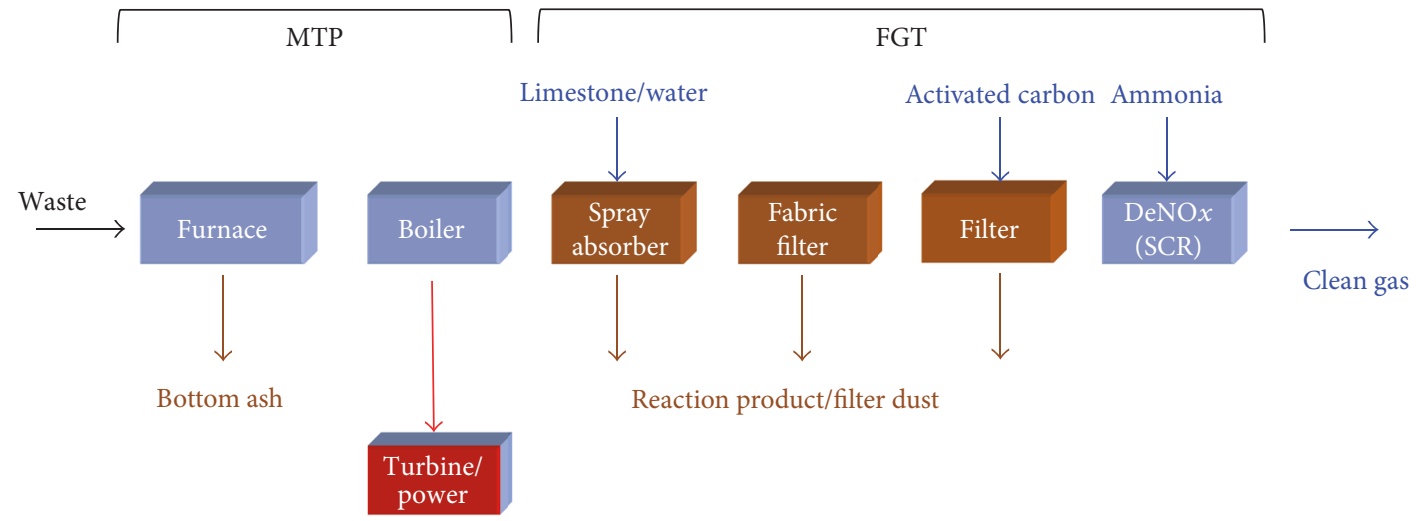

(b)

FiguRE 4: Summarized representation of both processes: (a) heat-conducted WtE plant with wet flue gas cleaning (option 1); (b) powerconducted WtE plant with dry flue gas cleaning (option 2). MTP: main thermal process, FGT: flue gas treatment, and ESP: electrostatic precipitator.

could be stated that the statistical entropy should be as low as possible for certain processes [4, chapter 7.2].

The statistical entropy $H$ is defined as

$$
H\left(c_{i, j}, m_{i}\right)=-\sum_{i=1}^{k} \bar{m}_{i} \cdot \bar{c}_{i, j} \cdot \log _{2}\left(\bar{c}_{i, j}\right)
$$

where $c_{i, j}$ is concentration of species $j$ in the mass $i$ and $m$ is normalized mass flow.

The relative statistical entropy $\Delta H_{\text {rel, } j}$ refers then to a maximum statistical entropy and is determined from the difference between input and output entropies for each species:

$$
\Delta H_{\text {rel }, j}=H_{\text {rel }, j, \text { input }}-H_{\text {rel }, j, \text { output }} .
$$

3.3. Energetic and Exergetic Assessment. Along with clean and hygienic treatment of waste the fundamental aim of waste management is to recover as much materials and energy as possible. Therefore, the energy conversion efficiencies of waste treatment processes are essential in the evaluation. The efficiencies $\eta$ are defined as ratio of useful output divided by the input. Input here is the chemical energy content of the waste; output is either thermal or electrical energy. The quality of both energy forms is different. This is considered in the so-called $R 1$ formula [2] where recovery option $R 1$ in Annex II of the Directive 2008/98/EC on waste (use of fuel to generate energy) can be distinguished from disposal operation D10 in Annex I of the same directive (incineration on land). Here thermal energy $Q$ is multiplied by a factor of 1.1 and electrical energy $E$ by a factor of 2.6

$$
R 1=\frac{1.1 Q+2.6 E}{\mathrm{NCV} \times m} .
$$

The $R 1$-formula above is a simplified equation without the use of imported energy and auxiliary fuels [12] with NCV, the net calorific value (see Table 1 ), and $m$, the mass flow of MSW incinerated.

The calculation of the exergy leads to similar results. The exergy factor of electricity is 1 , whereas thermal energy is taking into account the Carnot factor $1-\left(T_{0} / T\right)$ only (with $T$ the temperature of the thermal process and $T_{0}$ the surrounding temperature) [13]. 


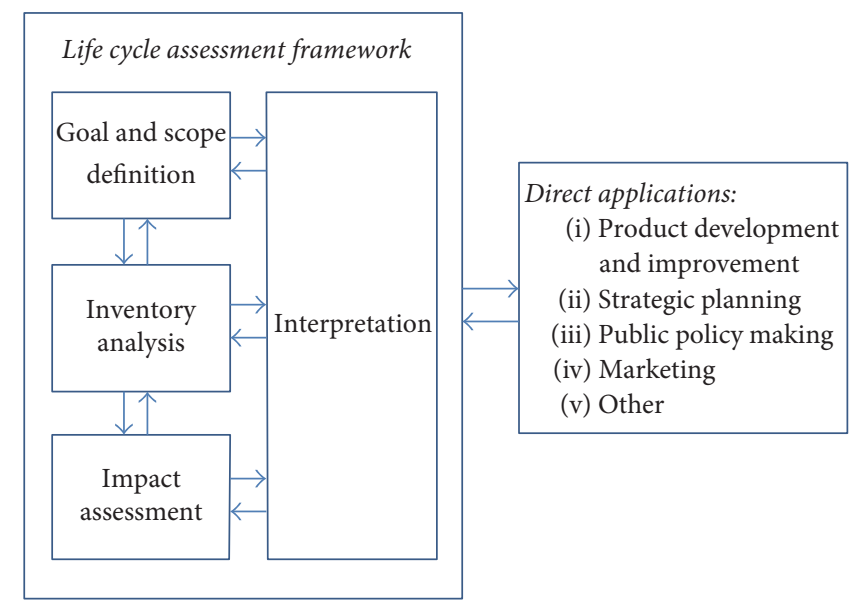

FIGURE 5: Stages of a life cycle assessment according to DIN EN ISO 14040 [15, p. 17].

3.4. Cumulative Energy Demand. The cumulative energy demand (CED) states the sum of the entire demand expressed as primary energy which arise from production $\left(\mathrm{CED}_{P}\right)$, use $\left(\mathrm{CED}_{U}\right)$, and end-of-life processes $\left(\mathrm{CED}_{E}\right)$ of a product or service [14]. For the process thermal waste treatment, $\mathrm{CED}_{P}$ is dominated by the cumulative energy demand for the materials such as steel, copper, concrete, and plastic used for building and facilities. $\mathrm{CED}_{U}$ is composed of the demand for operating consumables for combustion startup and flue gas cleaning (fuel oil, limestone, caustic soda, activated carbon for adsorption of organic pollutants, ammonia solution, precipitation agent TMT15 ${ }^{\circledR}$ (trimercapto-s-triacin, $15 \%$ aqueous solution of an organosulfide to capture heavy metals like $\mathrm{Pb}, \mathrm{Cd}, \mathrm{Cu}$, and $\mathrm{Hg}$ ), etc.), the plant's own use of electricity and steam, and useful energy to the grid. $\mathrm{CED}_{E}$ accounts for energy expenses for dismantling and final disposal of the plant.

3.5. Life Cycle Assessment. Life cycle assessments (LCAs) systematically analyse the environmental influences of products and processes as they span across multiple processes and the life cycle. LCAs should follow the norms ISO 14040 and ISO 14044, which describe the methodological foundation for carrying out life cycle assessments $[15,16]$. ure 5):

A life cycle assessment consists of four stages (see Fig-

(i) Goal and scope definition

(ii) Inventory analysis

(iii) Impact assessment

(iv) Interpretation.

Further guidance for LCA practitioners can be found in the International Reference Life Cycle Data system (ILCD) Handbook published be the JRC [17].

3.5.1. Goal and Scope Definition. The first stage defines the goals of the life cycle assessment being prepared. The study purpose and the intended audience or client for the study shall be named together with a clear definition of the goal. This clarifies, for example, whether this is a study to analyse representative questions for a particular region, or if the subject of the study is a specific product from a particular manufacturer. This piece of information then simultaneously serves to specify the temporal and spatial system boundaries and constrain the product system being studied.

In general, the goal of a life cycle assessment is to compare different products, processes, or services with the goal of supporting a decision to be made. Such comparisons require equivalent use of the functions of the products, processes, or services being compared. The ISO norm defines this requirement using a so-called functional unit, which quantitatively defines the benefit to which all results must bear reference. Such a function may exist, for example, in the packaging of a particular volume of a drink, in the transport of products over a specific distance, or in the treatment of a particular quantity of waste.

3.5.2. Inventory Analysis. In consensus with the defined goal and scope, the inventory analysis or life cycle inventory (LCI) stage is based on the model of the technical system to be analysed, the "product system." When carrying out a life cycle assessment in a complex product system, it is not always possible to determine all material and energy flows. Nevertheless, all "relevant" flows must be examined.

An additional methodological problem in the inventory analysis occurs for so-called multiproduct systems, for example, refining ores containing multiple different metals. In such cases, the input and output flows of the technical processes must be divided ("allocated") between the products involved.

3.5.3. Impact Assessment. Evaluation of the material flows determined in the inventory analysis with respect to their environmental influence takes place in the Life Cycle Impact Assessment (LCIA).

The ISO impact assessment rests upon the concept of category indicators, that is, on the determination of a quantitative indicator along the impact chain from material flows to potential harm to the environment. Table 3 summarizes 
TABLE 3: Examples of terms in an impact assessment (LCIA) DIN EN ISO 14044.

\begin{tabular}{ll}
\hline Term & Example \\
\hline $\begin{array}{l}\text { Impact category } \\
\text { LCI results }\end{array}$ & $\begin{array}{l}\text { Climate change } \\
\text { Amaracterisation model }\end{array}$ \\
$\begin{array}{l}\text { Aategory indicator } \\
\text { "Baseline" scenario of } 100 \text { years by the IPCC } \\
\mathrm{CO}_{2} \text {-eq./kg gas) }\end{array}$ & $\begin{array}{l}\text { Infrared radiative forcing }\left(\mathrm{W} / \mathrm{m}^{2}\right) \\
\text { Category indicator result }(\mathrm{kg}\end{array}$ \\
$\mathrm{CO}_{2}$-eq. per functional unit) & $\begin{array}{l}\text { Global warming potential }(\mathrm{GWP100}) \text { for each greenhouse gas } \\
\text { Kilograms of } \mathrm{CO}_{2} \text {-eq. per functional unit/global warming potential (GWP100) for each greenhouse }\end{array}$ \\
$\begin{array}{l}\text { Category endpoints } \\
\text { Coral reefs, forests, crops, human health (both increased mortality and morbidity), socioeconomic } \\
\text { impacts, for example, decreased productivity, major systems interruptions, for example, melting of } \\
\text { the Arctic ice sheet, and so on }\end{array}$ \\
$\begin{array}{l}\text { Infrared radiative forcing is a proxy for potential effects on the climate, depending on the integrated } \\
\text { atmospheric heat adsorption caused by emissions and the distribution over time of the heat } \\
\text { absorption }\end{array}$ \\
\hline
\end{tabular}

the impact category "global warming" of the defined environmental problem "greenhouse effect" as an example.

DIN EN ISO 14040 specifies that "the impact categories, category indicators and characterisation models should be internationally accepted, i.e., based on an international agreement or approved by a competent international body." In practice, frequently used impact categories include climate change, stratospheric ozone depletion, formation of photochemical oxidants (summer smog), acidification, and eutrophication as well as human and environmental toxicity. A quality assessment of different impact assessment methods can be found in the ILCD Handbook "Recommendation for Life Cycle Impact Assessment" [18]. Furthermore, abiotic resource consumption and CED (VDI 4600, see Section 3.4) are often specified as "input-related impact categories."

3.5.4. Interpretation. Life Cycle Interpretation, the important fourth and final stage, transforms the detailed and often complex results of the life cycle analysis and impact assessment into a message clearly comprehensible to the target audience. The ISO standards do not prescribe a mandatory procedure to be followed for the interpretation but do highlight the following important points: The results should bear clear reference to the goal and scope definition. Limitations should be explained and important points affecting the results or the choice of method should be described. DIN EN ISO 14044 lists the following components of the interpretation stage:

(i) Identification of the significant issues based on the results of the LCI and LCIA stage of LCA

(ii) Evaluation that considers completeness, sensitivity, and consistency checks

(iii) Conclusions, limitations, and recommendations.

3.6. Cost-Benefit Analysis and Eco-Efficiency Analysis. The cost-benefit analysis (CBA) is an instrument used to analyse action alternatives (e.g., when selecting projects) on a monetary basis [19]. In a CBA private monetary cost/benefit for the market participant themselves and social cost/benefit borne by the environment, which is not monetary in nature, can be accounted for

$$
\frac{\text { costs }}{\text { benefits }}=\frac{\text { private costs }}{\text { gains }}+\frac{\text { external costs }}{\text { gains }} \text {. }
$$

The eco-efficiency analysis evaluates ecological and economic aspects of product or process sustainability on equal footing [20]. The results are displayed in a portfolio with (normalized) costs and environmental burden which are derived from CBA and LCA, respectively.

\section{Results and Discussion}

4.1. Material Flow Analysis. In Figure 6, the flow charts of the total mass flows, the mass flows of mercury, zinc, and chlorine, are presented for both thermal waste treatment process chains as Sankey diagrams. Largest output fraction with solid residues is the bottom ash. Although the majority of zinc $(72 \%)$ is transferred to the bottom ash the concentrations of $\mathrm{Zn}$ in fly ash are higher $(5800 \mathrm{mg} / \mathrm{kg}$ versus $14000 \mathrm{mg} / \mathrm{kg}$ in the heat-conducted plant and $9300 \mathrm{mg} / \mathrm{kg}$ in the powerconducted plant, resp.) because the fly ash fraction is smaller by factor of 4-7. In the heat-conducted plant the wastewater fraction is the main output flow for chlorine. While the oceans are the final sink for the salts, minor part of chlorine is transferred to the fly ash. For the power-conducted plant, chlorine is mainly separated as alkaline earth chloride together with the fly ash by the fabric filter.

Due to the addition of TMT15, during waste-water treatment in the heat-conducted plant mercury is concentrated in the neutralization sludge, while in the power-conducted plant the mercury is adsorbed in activated carbon and separated in the fabric filter together with fly ash and reaction product. The other heavy metals, like $\mathrm{Ni}, \mathrm{Zn}, \mathrm{Cu}, \mathrm{Cr}, \mathrm{Cd}, \mathrm{Pb}$, and $\mathrm{As}$, are mainly distributed in the bottom ash and the fly ash.

4.2. Statistical Entropy Analysis. According to the definition of the relative statistical entropy with regard to the lowest concentration of the species in the earth crust, the first 

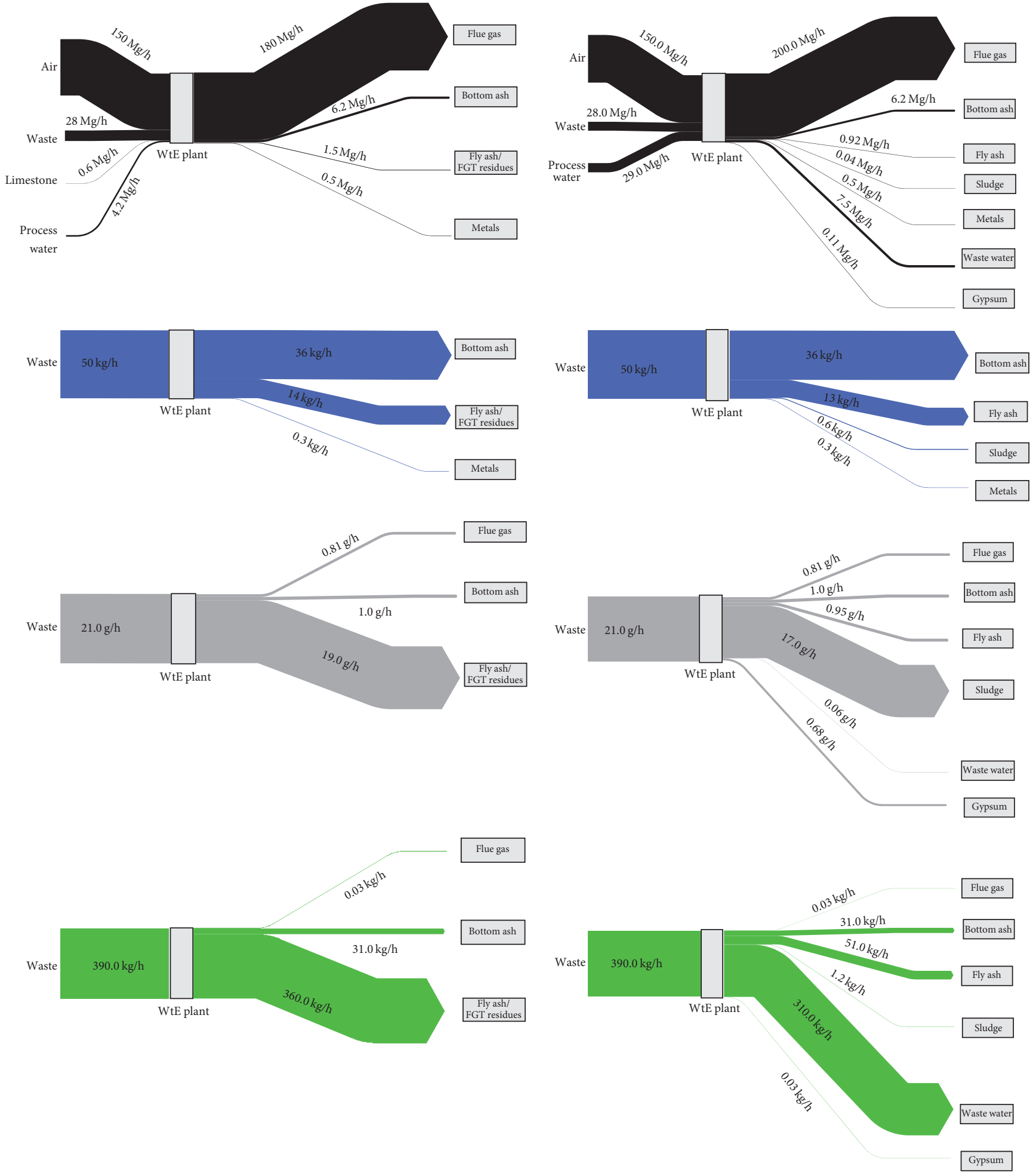

(a)

(b)

Figure 6: Material flow analysis for the mass flow (black), zinc (blue), mercury (gray), and chlorine (green) for heat-conducted (b) and power-conducted (a) WtE plants. 


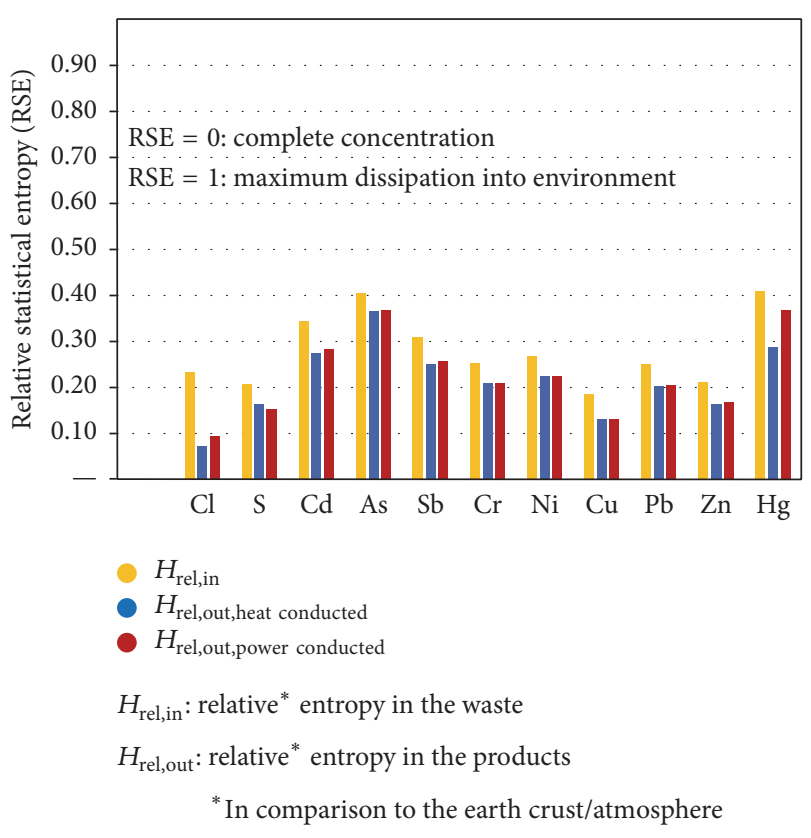

FIGURE 7: Statistical entropy analysis for chlorine, sulfur, and heavy metals for heat- and power-conducted WtE plants.

concentrating step took place in the waste generation itself. During the combustion of the waste in the WtE plant the species are concentrated in certain mass flows (see results of the material flow analysis). So in both cases $H_{\text {rel,out }}$ is lower than $H_{\text {rel,in }}$ in the waste flow. Differences result only for chlorine and mercury due the varying flue gas treatment technologies. Chlorine is concentrated in the waste-water discharge system in the case of the heat-conducted plant, where the concentration is higher than in the receiving river. In the power-conducted plant, mercury and chlorine are concentrated in the fly ashes and the reaction products. If the concentration $c_{j}$ of each species $j$ is high but the normalized mass flow $m_{i}$ is high, too, $H_{\text {rel }}$ will be higher than in the case where the concentration $c_{j}$ is high but the mass $m_{i}$ is low. For the power-conducted plant the normalized mass for the fly ashes and the reaction products is more than 20 times higher compared to the neutralization sludge in the heat-conducted plant while the concentration of mercury in both cases is more or less the same.

To wrap up the outcome of the statistical entropy and the material analysis, the heat-conducted plant has the ability to minimize the dissipation into environment for most of the mentioned species (Figure 7), by concentrating them in a certain mass flow or fraction. Although the mass flow of mercury in the flue gases and the bottom ash of both concepts is the same (Figure 6, gray flow sheets), $H_{\text {rel,out,heat conducted }}$ is still lower because mercury is concentrated in the sludge with a very small mass flow of about $0.04 \mathrm{Mg} / \mathrm{h}$ (Figure 6, black flow sheet, in (b)) compared, for example, to the much higher mass flow of fly ash and FGT residues with $1.5 \mathrm{Mg} / \mathrm{h}$ (Figure 6, black flow sheet, in (a)) for the power-conducted plant.
4.3. Energetic and Exergetic Assessment. For the comparison in the present work a net calorific value of $9720 \mathrm{~kJ} / \mathrm{kg}$ was established; see Table 1. This (chemical) energy content can only partly be utilized by the combustion process as thermal or electrical energy. The combustion parameters are of an overall air ratio of 1.6 , a thermal boiler efficiency of $86.2 \%$, and a net electrical efficiency of $6.6 \%$ for the heat-conducted plant and of $19.7 \%$ for the power-conducted WtE plant; the generated heat is exported into the grid with 5 bar and a feed temperature of $170^{\circ} \mathrm{C}$ and a return temperature of $55^{\circ} \mathrm{C}$. Thermal efficiencies are $63.8 \%$ (heat-conducted) and $1.6 \%$ (power-conducted), resulting in total efficiencies of 70.4 and $21.3 \%$, respectively. These results are in good agreement with a recent survey on efficiencies of European WtE plants [21]. According to this study, the average efficiency of powerconducted plants is $21.6 \%$ and $77.2 \%$ for a heat-conducted plant (100\% heat production). Combined heat and power (CHP) installations exhibit an average efficiency of $15 \%$ (power) and 37.1\% (heat).

The large difference between the calculated total efficiencies suggests a clear superiority of the heat-conducted WtE plant over the power-conducted plant. This is still true for the $R 1$ formula. $R 1$ for the heat-conducted WtE plant is calculated as 0.961 , and $R 1$ for the power-conducted plant is 0.599 , even though the share of electricity was multiplied by 2.6. The values for exergetic efficiencies are not surprisingly lower. The amount of generated electricity is multiplied by a factor of 1, the amount of generated district heat with 0.35 (using the Carnot factor for a temperature of $170^{\circ} \mathrm{C} ; T_{0}=$ $15^{\circ} \mathrm{C}$ ). The results show exergetic efficiencies of $28.7 \%$ (heatconducted) and $20.25 \%$ (power-conducted), respectively. The recovery of the elemental metals $\mathrm{Fe}, \mathrm{Al}, \mathrm{Cu}$, and brass alloys (see Table 1) can be attributed to an extra $1.6 \%$ for both processes.

4.4. Cumulative Energy Demand. $\mathrm{CED}_{P}$ was calculated for a waste incinerator in Germany with an annual capacity of $107000 \mathrm{Mg}$ per year [22] with a result of $47 \mathrm{MJ}$ per $\mathrm{Mg}$ of waste treated. More than $50 \%(24.4 \mathrm{MJ} / \mathrm{Mg})$ is attributed to steel used in components of the WtE plant (e.g., boiler or turbines), followed by steel for the building envelope $(14.2 \mathrm{MJ} / \mathrm{Mg})$. This figure is smaller than $\mathrm{CED}_{U}$ related to operating consumables with 100 and $170 \mathrm{MJ} / \mathrm{Mg}$ waste for the heat-conducted and power-conducted plant, respectively. The discrepancy arises from the different flue gas cleaning system (CED for limestone and coke). Plant's own use of energy is in both alternatives on the same level (heat-conducted: $3335 \mathrm{MJ} / \mathrm{Mg}$; power-conducted: $3165 \mathrm{MJ} / \mathrm{Mg}$ ). Useful energy to the grid differs largely: $10029 \mathrm{MJ} / \mathrm{Mg}$ for the heat-conducted plant and $4338 \mathrm{MJ} / \mathrm{Mg}$ for the power-conducted plant. Primary energy conversion factors for heat and electricity were retrieved from literature: $1.31 \mathrm{MJ} / \mathrm{MJ}_{\text {heat }} ; 2.31 \mathrm{MJ} / \mathrm{MJ}_{\text {electricity }}[23,24] . \mathrm{CED}_{E}$ was estimated to be negligible. The bottom line is a negative value for total CED in both alternatives: $-6672 \mathrm{MJ} / \mathrm{Mg}$ waste for the heat-conducted plant; $-1472 \mathrm{MJ} / \mathrm{Mg}$ for the powerconducted plant. The results show that the outcome of the CED analysis is dominated by the use phase. The impact related to facilities and equipment $\left(\mathrm{CED}_{P}\right)$ is small. The effect of such capital goods has only rarely been addressed 
systematically in LCA studies on WtE technologies [25]. From the results in the present work, neglecting the environmental impact related to capital goods seems to be justified.

\subsection{Life Cycle Assessment}

4.5.1. Goal and Scope Definition. The aim of the present life cycle assessment is to compare two WtE plants which differ with respect to the parameters for the energy output (power-conducted or heat-conducted) and the applied flue gas cleaning processes. The system boundaries include a $\mathrm{WtE}$ plant with the flue gas and waste-water treatment, the complete energy conversion part, and the entire upstream chains for the provision of all required resources, starting with the extraction from the ecosphere. The construction of the WtE plants along with their infrastructure was considered negligible and is therefore not included in the balance sheet. The functional unit includes the treatment of $1 \mathrm{Mg}$ of municipal waste in the WtE plant. It is important to make sure that the benefits/performances of both compared systems are the same. Since both studied options have different "added values" (in the case of the present study-electricity or heat generation), the equivalent processes will be deducted from the environmental impact as environmental credits.

4.5.2. Life Cycle Inventory. The life cycle inventory (LCI) includes all relevant materials and energy flows from both compared processes (see Figure 4). The processes are modelled as a single chart without separate representation of the individual plant components (among which are combustion, energy conversion, and gas treatment) - the so-called "black box" modelling. The models are developed with the open source LCA software OpenLCA (http://www.openlca.org).

4.5.3. Impact Assessment. The present LCA aims to provide an example depiction of the processes. Therefore, only the GWP (global warming potential) measured in $\mathrm{kg}$ $\mathrm{CO}_{2}$-eq./Mg will be taken into consideration as impact category. Two other impact categories, that is, acidification potential and human toxicity potential, have been calculated as well. Figure 8 depicts the GWP of both WtE plants calculated using the impact assessment method developed at Centrum voor Milieukunde, Leiden University, in The Netherlands (the CML impact assessment method), which analyses effects of the greenhouse gas (GHG) emissions over a time span of 100 years.

Concerning the amount of GHG emissions, both processes come up with similar GWP values $\left(845 \mathrm{~kg} \mathrm{CO}_{2}\right.$-eq./Mg for power-conducted WtE plants versus $851 \mathrm{~kg} \mathrm{CO}$-eq. $/ \mathrm{Mg}$ for heat-conducted WtE plants). While the major part of the emissions comes from the biogenic fraction of combustion (501 kg $\mathrm{CO}_{2}$-eq./Mg of waste), only a very small part of GHG emissions ( $0.46 \mathrm{~kg} \mathrm{CO}_{2}$-eq./Mg waste) results from the combustion of fuel oil required for the operation of the $\mathrm{WtE}$ plants.

The generated amounts of heat and electricity as well as the produced substitutes for primary materials during the metal manufacturing (iron, copper, and aluminum) will be taken into consideration by deducing of the emission
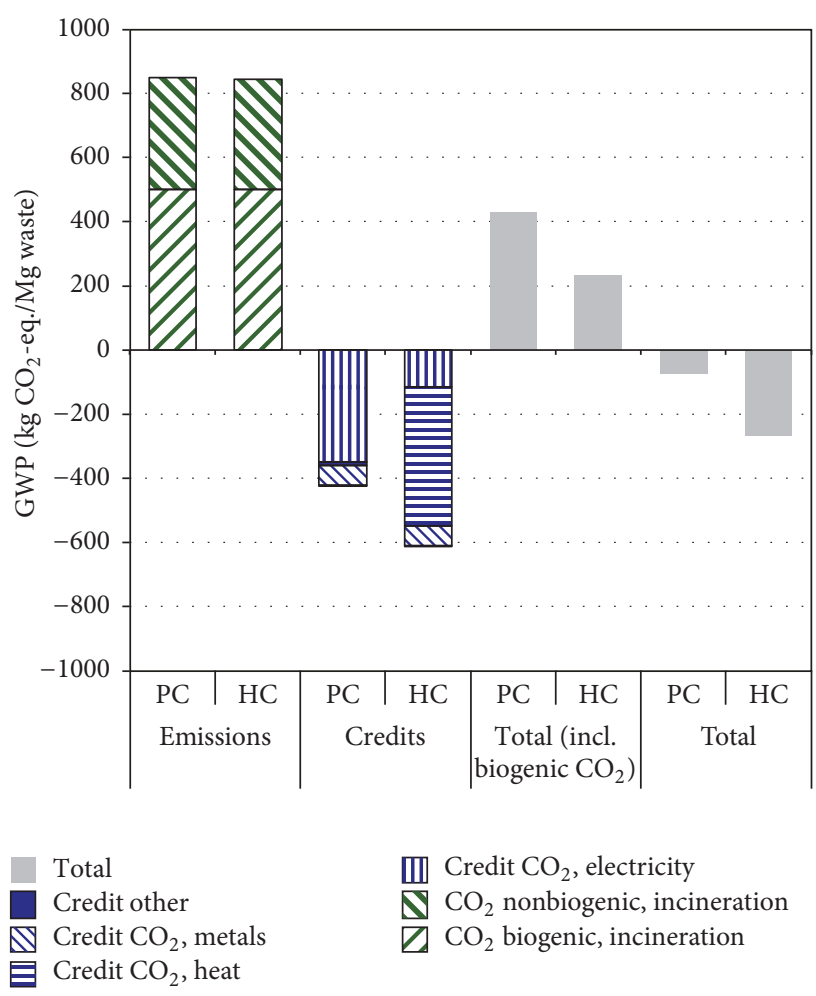

III Credit $\mathrm{CO}_{2}$, electricity

$\Delta \mathrm{CO}_{2}$ nonbiogenic, incineration

$\square \mathrm{CO}_{2}$ biogenic, incineration

FIGURE 8: GWP of the power-conducted (PC) and heat-conducted (HC) WtE plants.

credits (depending on the electricity mix of the providing power plant parks). The data for the electricity mix were obtained from Itten et al. [26]. According to that work, the German electricity production is mainly powered by fossil fuels (22\% lignite, 18\% coal, and 13\% natural gas), by nuclear power $(22 \%)$, and by renewable energy sources (6\% of the total amount, mainly by wind power plants), while $7 \%$ of the electricity is imported from the neighboring countries. Proceeding from these assumed data, the impact assessment returns the GWP value of $671.5 \mathrm{~g} \mathrm{CO}_{2} / \mathrm{kWh}$ for the German electricity mix. For comparison, the values are $109.0 \mathrm{~g} \mathrm{CO}_{2} / \mathrm{kWh}$ for the electricity mix in France and $1209.0 \mathrm{~g} \mathrm{CO}_{2} / \mathrm{kWh}$ for Poland. The data for the heat mix were obtained from the AGFW [27]. According to these data, the heat mix consists of natural gas $(46,25 \%)$ and other heat sources like coal, biomass, and so on $(53.75 \%)$. The GWP calculations of the heat production in Germany based on these data result in $250 \mathrm{~g} \mathrm{CO} / \mathrm{kWh}$. The GHG avoided corresponds to $611 \mathrm{~kg} \mathrm{CO}_{2}$-eq. $/ \mathrm{Mg}$ waste for the heat-conduction $\mathrm{WtE}$ and $424 \mathrm{~kg} \mathrm{CO}$-eq./Mg waste for the power-conducted $\mathrm{WtE}$, respectively.

For the case where only gas power plants are taken into account (and not the plants powered by the German heat mix), the power-conducted WtE plant compensates only 4.36 $\mathrm{CO}_{2}$-eq./Mg of waste and the heat-conducted alternative compensates $171.85 \mathrm{~kg} \mathrm{CO}$-eq./Mg of the municipal waste (see Figure 9). Should coal power plants be considered as the only heat suppliers, the heat-conducted option would 


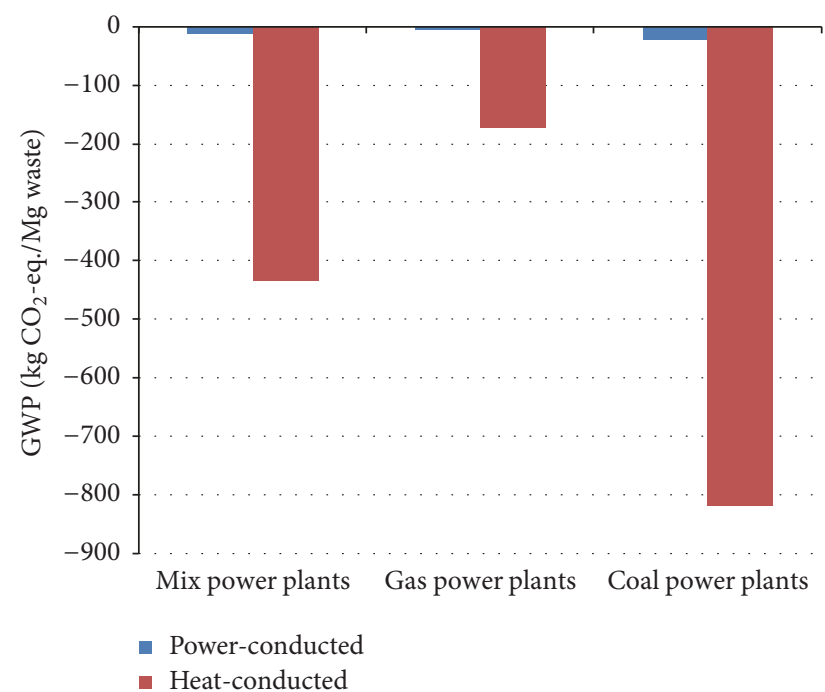

FIGURE 9: Heat credits for greenhouse effect GWP of powerconducted and heat-conducted WtE plants compared regarding different types of power plants.

compensate $817.18 \mathrm{~kg} \mathrm{CO}_{2}$-eq. $/ \mathrm{Mg}$ of waste and the powerconducted WtE plant would compensate $20.78 \mathrm{~kg} \mathrm{CO}_{2}$ eq./ $\mathrm{Mg}$ of waste. This means that the credit values vary depending on the chosen heat source, so the comparison methodology for environmental credits should always be chosen as close as possible to the actual situation. For example, the choice of coal plants as the only source of heat would mean a higher credit value. This choice is however not justified since the German heat mix has a significantly different composition.

The importance of the substituted energy is also shown in the work of Jeswani and Azapagic [28] comparing waste incineration with landfilling. The credits for replaced greenhouse gas emissions are lower if the WtE plant substitutes cleaner electricity. The global warming potential of the WtE plant therefore shows emissions instead of savings in the case of substituted energy from the UK grid, from natural gas, or from nuclear power. Greenhouse gas savings occur looking at the use of heavy fuel oil and coal.

4.5.4. Interpretation, Data Analysis, and Evaluation. There are several ways to depict the coproducts in the model (among which are mainly electricity and heat in the present study). One possibility is the allocation (distribution) of the environmental impacts within a particular aspect for different products (e.g., physical or economical aspects). Since the disposal of $1 \mathrm{Mg}$ of waste in the described WtE plants cannot be allocated directly to electricity or heat, the modelled systems should be extended by using the environmental credits. This means that the environmental impacts of the German power plants are credited by the generation of, for example, electricity.

The availability of data forms the boundaries of the LCA. The data gaps for certain emissions or critical processes may lead to completely false results for the associated impact categories or the entire life cycle assessment (e.g., if there is no data on GHG emissions, one cannot carry out the assessment of the global warming potential). Regarding all these limitations, the heat-conducted WtE plant should be preferred from the climate perspective (see Figure 9).

4.6. Cost-Benefit Analysis and Eco-Efficiency Analysis. Costbenefit analysis revealed that at similar treatment cost (fixed cost for, e.g., debt service and variable cost for consumables) for both options of around 130 Euros/Mg the revenues from energy production are much higher for the heat-conducted plant (155 Euros/Mg) than for the power-conducted plant (65 Euros/Mg) even though the return per MWh is higher for electricity (115 Euros/MWh compared to 75 Euros/MWh, see the same discussion for efficiencies in Section 4.3). This leads also to a better eco-efficiency of the heat-conducted plant: better environmental performance regarding greenhouse gas emission (see Figure 8) and lower overall cost or, as in this case, higher revenues (-27 Euros/Mg compared to 67 Euros/Mg).

Monetization factors for external effects can be used from existing models, for example, from the EPS method (Environmental Priority Strategy) [29]. Here $\mathrm{CO}_{2}$ is valuated with 108 Euros/Mg, and emissions from Particulate Matter $\left(\mathrm{PM}_{10}\right)$ are valuated with 36000 Euros/Mg. The monetized environmental burdens from both alternatives are almost identical (40.5 Euros/Mg waste power-conducted; 39.2 Euros/Mg waste heat-conducted). However, in total with the credits from energy production the result is different: -17.5 Euros $/ \mathrm{Mg}$ waste for the power-conducted plant and -49.8 Euros $/ \mathrm{Mg}$ waste for the power-conducted plant (i.e., net environmental benefits).

Not surprisingly the results for the eco-efficiency analysis are similar. Because the heat-conducted plant is in most LCA impact categories the superior alternative and is economically more favorable, in the eco-efficiency portfolio, this alternative is placed in the upper right quadrant (low normalized cost and low normalized environmental impact). The powerconducted plant is more expensive and has a higher environmental impact. Therefore, the power-conducted plant ends up in the lower left quadrant; see Figure 10.

\section{Discussion and Conclusions}

"What is the best way to manage urban waste?" was asked in a special issue of EU's DG Environment News Alert Service [30]. The question is not easy to answer. This is the reason why hundreds of LCA case studies of solid waste management systems or WtE technologies have been performed. At least it is clear that landfilling without any energy recovery such as biogas utilization is the worst option. For a sustainable waste management 5 main targets can be defined [31]: (1) protection of man and environment, (2) conservation of resources, (3) waste disposal in regional and temporal responsibility, (4) organization of waste management in an economically acceptable way, and (5) social compatibility of waste management. Protection of man and environment can be achieved with technical systems. Even when waste is landfilled, emissions to groundwater or air can be prevented with technical barriers composed of geotechnical products [32]. 


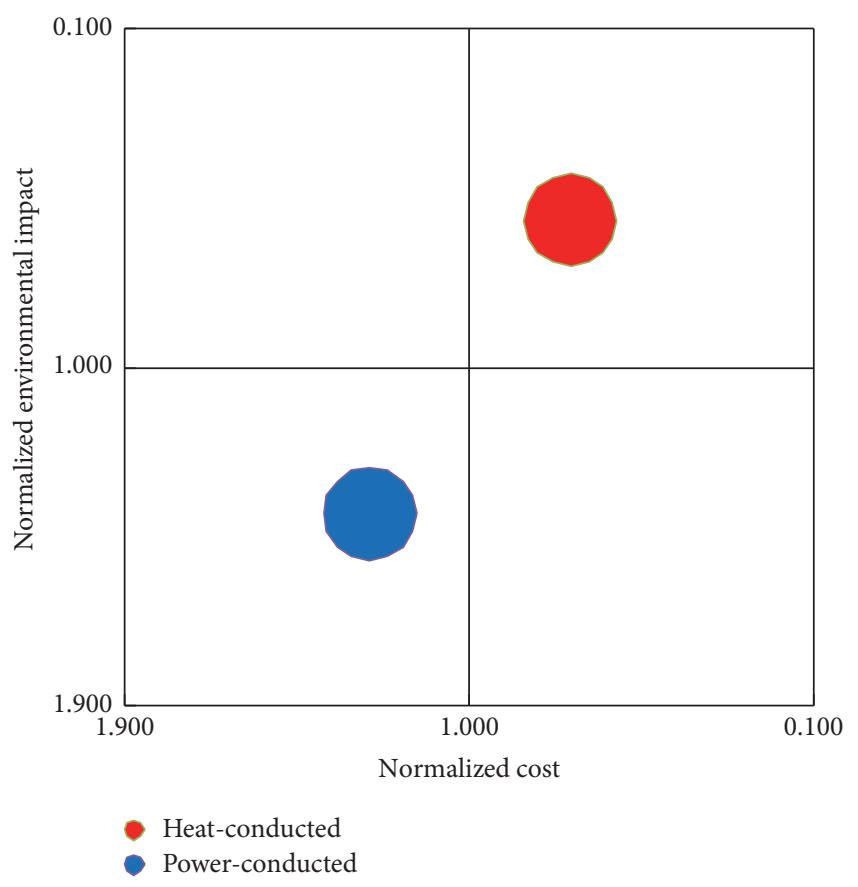

FIGURE 10: Results from the eco-efficiency analysis; see text.

For thermal waste treatment the best available techniques have been compiled in a reference document (WI BREF [33]). Application of these techniques in waste incineration ensures protection of man and environment.

Conservation of resources is possible in various ways in waste treatment. Specific waste streams such as paper, plastic, metals, or glass can be separated at the source (see Figure 2) for recycling [34]. For paper and glass there is consensus that this is preferable compared to thermal waste treatment of nonseparated solid waste [25]. Management of plastic waste is controversial [35]. Collection and recycling of plastic waste are most probably beneficial when monofractions can be generated. However, waste incineration with energy recovery could be a better option for contaminated polymers with impurities [36]. Recovery of elemental metals, that is, ferrous and nonferrous metals, is easier subsequent to thermal waste treatment because plastic-metal composites and all kinds of coatings are effectively removed by the incineration process. The metals can then be separated almost completely from the bottom ash [37]. Here the revenues are much higher than the treatment cost.

However, for the recovery of chemical bound metals from waste incineration residues the situation is different. This was evaluated in the case of zinc. With material flow analysis (see Section 3.1) it was shown that, from a flow of $50 \mathrm{~g} / \mathrm{h} \mathrm{Zn}$, $26 \%(13 \mathrm{~g} / \mathrm{h})$ are transferred to the fly ash and $72 \%$ to the bottom ash (residual $2 \%$ to other output fractions). The $\mathrm{Zn}$ concentration in the fly ash can then be calculated from the mass balance of the process (see Figure 6) to $14,000 \mathrm{mg} / \mathrm{kg}$ fly ash (heat-conducted). In the power-conducted plant the concentration in the fly ash is lower because also the reaction products from flue gas cleaning are contained in this fraction and cause a dilution. Concentrations of $\mathrm{Zn}$ in fly ash of electrostatic precipitators (ESP) in WtE plants can be as high as $42,000 \mathrm{mg} / \mathrm{kg}$ [38]. Zinc can be recovered from the ash with the hydrochloric acid $(\mathrm{HCl})$ which is produced in the first step of a wet flue gas cleaning system (see Figure 4). For this scenario, $\mathrm{HCl}$ utilization from wet flue gas cleaning system and high concentrations in ESP fly ash, the production cost of $\mathrm{Zn}$ is in the range of the market price. With dry or semidry flue gas cleaning systems, the production cost of secondary $\mathrm{Zn}$ is higher than the market price by a factor of up to 10 $[38,39]$. Zn recovery from fly ash is applied in Switzerland although the process is hardly economical [38]. Obviously, the goals of conservation of resources and waste disposal in regional responsibility (see sustainability targets (2) and (3) above) are there considered as high priority.

The present study shows that WtE plants generating district heat or process steam have economic and ecological advantages compared to power-conducted WtE plants. One reason for this is falling earnings from electricity as a result of increasing share of renewable energy in electricity generation, for example, in Germany. However, a stable demand for district heat (which requires appropriate infrastructure) or process steam is a prerequisite for the operation of a heatconducted WtE plant. The infrastructure and market for heat and steam are not available everywhere [40]. In contrast, electricity generated in a power-conducted plant can be easily transferred to the grid.

As long as avoidance of waste and reuse is not completely achievable, thermal waste treatment with recovery of energy and secondary raw materials is a necessary waste management option. It was shown that methods for the evaluation of to what extent sustainability goals are achieved by a certain waste management option exist.

\section{Conflicts of Interest}

The authors declare that they have no conflicts of interest.

\section{References}

[1] Eurostat, Environment in the EU, Each person in the EU generated $475 \mathrm{~kg}$ of municipal waste in $2014,44 \%$ was recycled or composted, Press release, 56/2016, 2016.

[2] European Parliament and the Council, Directive on waste and repealing certain directives 2008/98/EC, Official Journal of the European Union L312, 2008.

[3] G. Dehoust, R. O. Harthan, H. Stahl, H. Hermann, F. C. Matthes, and A. Möck, "Beitrag der Kreislaufwirtschaft zur Energiewende, Klimaschutzpotenziale auch unter geänderten Rahmenbedingungen optimal nutzen, Study for BDE Bundesverband der deutschen Entorgungswirtschaft," Öko-Institut e.V, 2014.

[4] Verein Deutscher Ingenieure, VDI 3925, Part 1: Methods for evaluation of waste treatment processes, Beuth Verlag, Berlin, 2016.

[5] J. Wagner, K. Heidrich, J. Baumann, T. Kügler, and J. Reichenbach, "Determination of the contributions of the waste management sector to increasing resource productivity and of the share recycling takes in the value-added chain displaying the paths of Texte, UBA-FB (14/2012) recovery of relevant waste," INTECUS, 
Waste Management and Environment-integrating Management, 2012.

[6] A. J. Morrissey and J. Browne, "Waste management models and their application to sustainable waste management," Waste Management, vol. 24, no. 3, pp. 297-308, 2004.

[7] F.-G. Simon and M. Hiebel, "Bewertung von Abfallbehandlungsverfahren: Entscheidungsunterstützung durch die neue VDI-Richtline 3925," Chemie Ingenieur Technik, vol. 86, no. 11, pp. 1954-1964, 2014.

[8] Verein Deutscher Ingenieure, Methoden zur Bewertung von Abfallbehandlungsanlagen - Beispielrechnungen, VDI Guideline (draft), 3925, Blatt 2, 2016.

[9] Verein Deutscher Ingenieure, VDI 3460, Emission Control, Thermal waste treatment, Fundamentals (Part 1), Beuth Verlag, Berlin, 2014.

[10] P. H. Brunner and H. Rechberger, "Practical handbook of material flow analysis," The International Journal of Life Cycle Assessment, vol. 9, no. 5, pp. 337-338, 2004.

[11] H. Rechberger and P. H. Brunner, "A new, entropy based method to support waste and resource management decisions," Environmental Science \& Technology, vol. 36, no. 4, pp. 809-816, 2002.

[12] K. Wielenga, "Waste-to-Energy and the revision of the Waste Framework Directive, Waste-to-Energy's contribution to climate protection Report, FF/KW/2008.002-01. FFact, Braine l'Alleud," Tech. Rep., 2008.

[13] F.-G. Simon and O. Holm, "Exergetic considerations on the recovery of metals from waste," International Journal of Exergy, vol. 19, no. 3, pp. 352-363, 2016.

[14] Verein Deutscher Ingenieure, VDI 4600, Cumulative energy energy demand (KEA) - Terms, definitions, methods of calculations, Beuth Verlag, Berlin, 2012.

[15] DIN EN ISO 14040:2009, Umweltmanagement. Ökobilanz. Grundsätze und Rahmenbedingungen. Deutsches Institut für Normung e.V., 2009.

[16] DIN EN ISO 14044:2009, Umweltmanagement. Ökobilanz. Anforderungen und Anleitungen. Deutsches Institut für Normung e.V., 2006.

[17] European Commission Joint Research Centre (JRC), International Reference Life Cycle Data System (ILCD) Handbook: General guide for Life cycle Assessment - Detailed guidance, EUR 24708, JRC 48157, 2010.

[18] European Commission Joint Research Centre (JRC), International Reference Life Cycle Data System (ILCD) Handbook: Recommendations for Life Cycle Impact Assessment in the European context, EUR 24571, JRC 61049, 2011.

[19] A. E. Boardman, D. H. Greenberg, A. R. Vining, and D. L. Weimer, Cost Benefit Analysis: Concepts and Practice, Prentice Hall, Upper Saddle River, New Jersey, USA, 2006.

[20] P. Saling, A. Kicherer, B. Dittrich-Krämer et al., "Eco-efficiency analysis by BASF: The method," The International Journal of Life Cycle Assessment, vol. 7, no. 4, Article ID BF02978875, pp. 203218, 2002.

[21] D. O. Reimann, "Results of specific data for energy," III (Status 2007-2010). CEWEP, 2012.

[22] W. Mauch, "Kumulierter Energieaufwand für die Müllabfuhr, Müllverbrennung und Deponierung," Abfallwirtschafts Journal, vol. 4, no. 3, pp. 240-249, 1992.

[23] R. Karpf, Emissionsbezogene Energiekennzahlen von Abgasreinigungsverfahren bei der Abfallverbrennung, TK Verlag, Neuruppin, 2012.
[24] Ökoinstitut e.V., Prozessorientierte Basisdaten für Umweltmanagement-Instrument ProBas, Web-Datenbank, http://www .probas.umweltbundesamt.de/. Umweltbundesamt, 2008.

[25] T. F. Astrup, D. Tonini, R. Turconi, and A. Boldrin, "Life cycle assessment of thermal Waste-to-Energy technologies: Review and recommendations," Waste Management, vol. 37, pp. 104-115, 2015.

[26] R. Itten, R. Frischknecht, and M. Stucki, Life Cycle Inventories of Electricity Mixes and Grid. treeze Ltd, CH, Uster, 2014.

[27] AGFW, "AGFW-Hauptbericht 2012 des Energieeffizienzverband für Wärme, Kälte und KWK e.V", Frankfurt am Main, 2013.

[28] H. K. Jeswani and A. Azapagic, "Assessing the environmental sustainability of energy recovery from municipal solid waste in the UK," Waste Management, vol. 50, pp. 346-363, 2016.

[29] B. Steen, "A systematic approach to environmental priority strategies in product development (EPS). Version," in Models and data of the default method, CPM report 1999:5. Centre for Environmental Assessment of Products and Material Systems, CPM report 1999, 5. Centre for Environmental Assessment of Products and Material Systems, 2000.

[30] European Commission DG Environment, What is the best way to manage urban waste?, Science for Environment Policy (Special Issue 11) 2009.

[31] R. Winzeler, P. Hofer, and L. S. Morf, “Towards Sustainable Waste Management," in Municipal solid waste management, C. Ludwig, S. Hellweg, and S. Stucki, Eds., pp. 462-513, Springer, Berlin, 2003.

[32] F.-G. Simon and W. W. Müller, "Standard and alternative landfill capping design in Germany," Environmental Science \& Policy, vol. 7, no. 4, pp. 277-290, 2004.

[33] European Commission, Reference Document on the Best Available Techniques for Waste Incineration. European IPPC Bureau at the Institute for Prospective Technological Studies, Sevilla, Spain, 2006.

[34] C. Wünsch and F.-G. Simon, "The Reduction of Greenhouse Gas Emissions Through the Source-Separated Collection of Household Waste in Germany," in The Handbook of Environmental Chemistry, Springer, Berlin, Heidelberg, 2017.

[35] L. Rigamonti, M. Grosso, J. Møller, V. Martinez Sanchez, S. Magnani, and T. H. Christensen, "Environmental evaluation of plastic waste management scenarios," Resources, Conservation \& Recycling, vol. 85, pp. 42-53, 2014.

[36] F.-G. Simon and K. Keldenich, "Waste management between thermal treatment and recycling," Chemie Ingenieur Technik, vol. 84, no. 7, pp. 985-990, 2012.

[37] O. Holm and F.-G. Simon, "Innovative treatment trains of bottom ash (BA) from municipal solid waste incineration (MSWI) in Germany," Waste Management, vol. 59, pp. 229-236, 2017.

[38] J. Fellner, J. Lederer, A. Purgar et al., "Evaluation of resource recovery from waste incineration residues - The case of zinc," Waste Management, vol. 37, pp. 95-103, 2015.

[39] A. Purgar, F. Winter, D. Blasenbauer et al., "Main drivers for integrating zinc recovery from fly ashes into the Viennese waste incineration cluster," Fuel Processing Technology, vol. 141, pp. 243-248, 2016.

[40] S. Burnley, T. Coleman, and A. Peirce, "Factors influencing the life cycle burdens of the recovery of energy from residual municipal waste," Waste Management, vol. 39, pp. 295-304, 2015. 


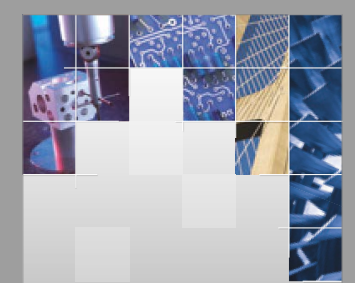

\section{Enfincering}
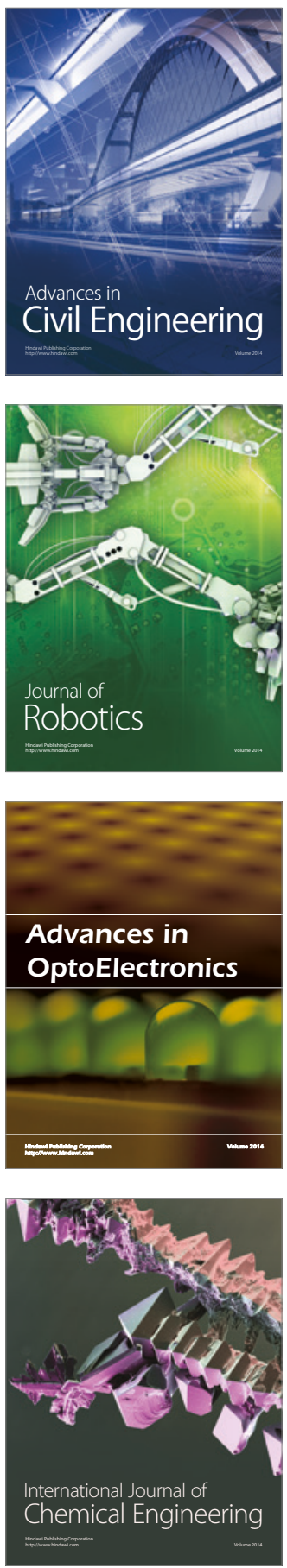

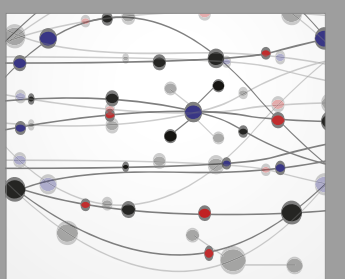

The Scientific World Journal

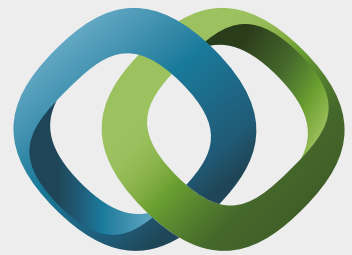

\section{Hindawi}

Submit your manuscripts at

https://www.hindawi.com
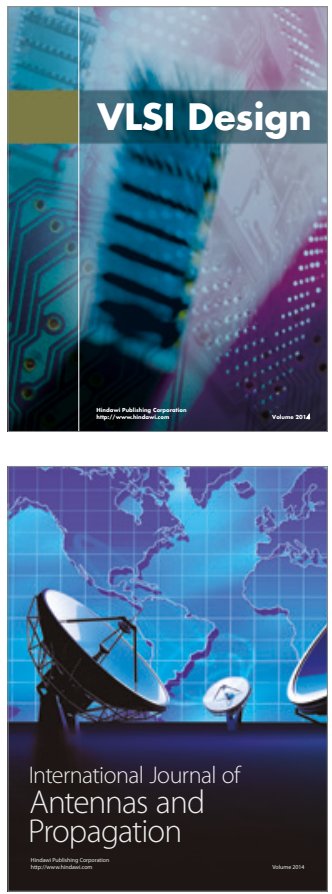

\section{Rotating}

Machinery
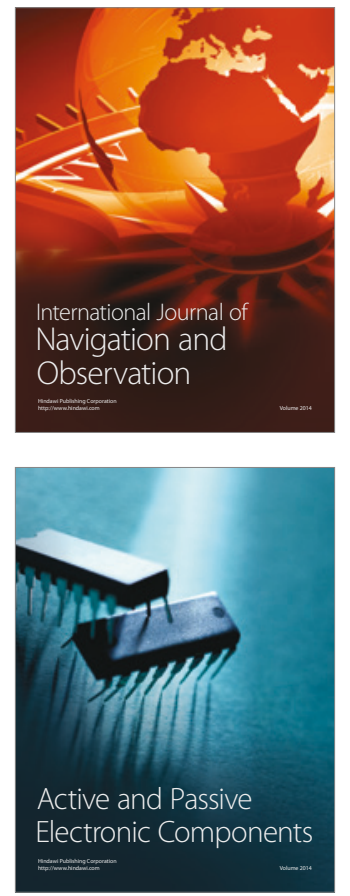
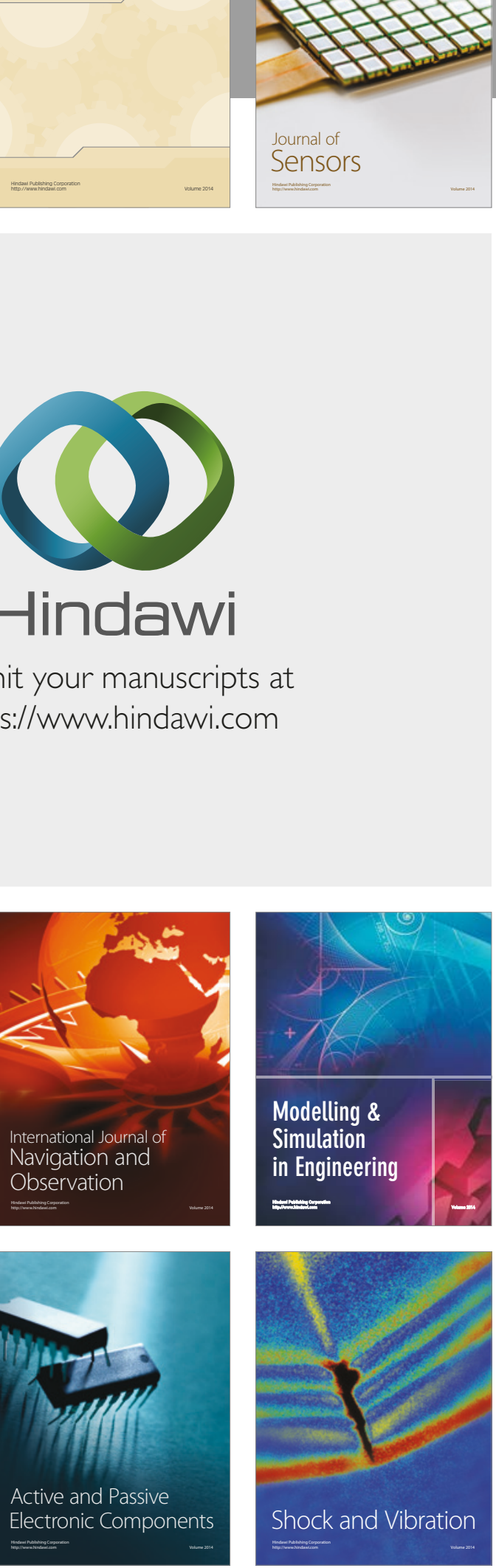
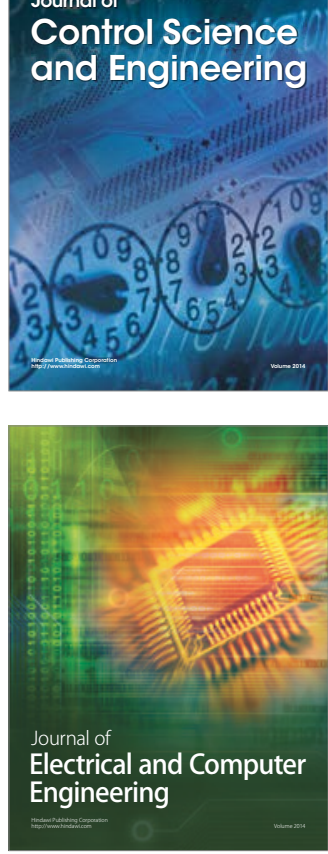

Distributed

Journal of

Control Science

and Engineering
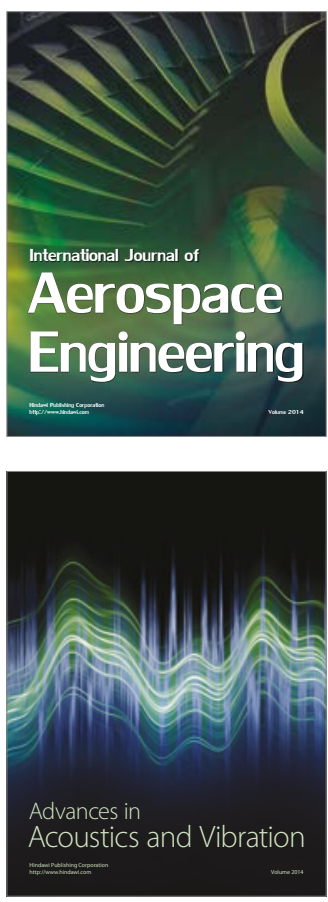

Sensor Networks 